\title{
Magnesium-doped Zinc Oxide as a High Resistance Transparent Layer for thin film CdS/CdTe solar cells
}

\author{
Francesco Bittau ${ }^{1}$, Elisa Artegiani ${ }^{2}$, Ali Abbas ${ }^{1}$, Daniele Menossi $^{2}$, Alessandro Romeo ${ }^{2}$ \\ , Jake W. Bowers ${ }^{1}$ and John M. Walls ${ }^{1}$ \\ ${ }^{1}$ Centre for Renewable Energy Systems Technology (CREST), Wolfson School of Mechanical, \\ Electrical and Manufacturing Engineering, Loughborough University, Loughborough, Leicestershire, \\ LE11 3TU, UK \\ ${ }^{2}$ Laboratory for Applied Physics, Department of Computer Science, Univ. Verona, \\ Strada Le Grazie 15, 37134, Verona, Italy
}

\begin{abstract}
Magnesium-doped Zinc Oxide (MZO) was used as an alternative high resistance transparent layer for $\mathrm{CdS} / \mathrm{CdTe}$ thin film solar cells. Thin films of MZO were deposited by RF magnetron sputtering and deposited on an Indium Tin Oxide contact (ITO). Thin film CdTe devices including a MZO high resistance transparent layer deposited at above $300{ }^{\circ} \mathrm{C}$ yielded a mean efficiency exceeding $10.5 \%$. This compares with an efficiency of $8.2 \%$ without the MZO layer. The improvement in efficiency was due to a higher open circuit voltage and fill factor. Lowering the deposition temperature of MZO reduced the performance of the devices.

Index Terms - magnesium-doped zinc oxide, high resistance transparent layer, thin film, solar cells, CdTe.
\end{abstract}

\section{INTRODUCTION}

Doping $\mathrm{ZnO}$ with $\mathrm{MgO}\left(E_{G}=7.7 \mathrm{eV}\right)$ leads to an energy bandgap increase $\left(E_{G} \approx 3.3 \mathrm{eV}\right.$ [1]-[3]) through the formation of $\mathrm{Zn}_{1-x} \mathrm{Mg}_{x} \mathrm{O}$ (MZO) [4]. The increase depends linearly upon the $\mathrm{Mg}$ content in the film, up to a $\mathrm{Mg}$ content of $\mathrm{x}=0.46$, at which point the band gap becomes $E_{G}=4.2 \mathrm{eV}$ [5]. Experimental determination of the band alignment of MZO indicates that the larger band gap of MZO is almost exclusively due to an upshifting of the conduction band energy level [6], [7]. A similar behaviour occurs when $\mathrm{ZnO}$ is doped with $\mathrm{Ca}$ rather than $\mathrm{Mg}$ [8], [9]. In the range $\mathrm{x}=0$ to $\mathrm{x}=0.46 \mathrm{Zn}_{1-x} \mathrm{Mg}_{x} \mathrm{O}$ maintains the typical hexagonal structure of $\mathrm{ZnO}$. Above this doping level there is a gradual transition to the cubic structure of $\mathrm{MgO}$ [5]. There are several studies highlighting the importance of controlling the alignment between the band levels of absorber and window layers in chalcogenide solar cells [10][12]. These emphasize the importance of a slightly positive conduction band at the buffer/absorber interface to control the inversion of the absorber and recombination at the interface. The first applications of MZO were reported with copper indium gallium selenide (CIGS) thin film solar cells [13][17], where $\mathrm{MZO}$ was used as a replacement for the $\mathrm{CdS}$ buffer layer. The successful application of magnesium-doped zinc oxide to CdTe thin film solar cells has been reported recently [18]. Other semiconductors have been investigated for the tuneability of their energy band structure [19]-[23]. This study has focused on using MZO as an HRT layer with an emphasis on the effect of changing its conduction band alignment with the adjacent semiconductors by varying the temperature.

\section{EXPERIMENTAL Details}

Tin-doped indium oxide and magnesium-doped zinc oxide thin films were deposited by Radio-Frequency (RF) magnetron sputtering. Soda lime glass (SLG) was used as a superstrate. The glass was cleaned using a solution composed of $1 / 3$ isopropanol, $1 / 3$ acetone and $1 / 3$ deionized water in an ultrasonic bath at $50{ }^{\circ} \mathrm{C}$ for $60 \mathrm{~min}$. Thin films were deposited using an Orion $8 \mathrm{HV}$ magnetron sputtering system (AJA international, USA) equipped with an AJA 600 series RF power supply. The 3" diameter ITO target contained 10 $\% \mathrm{SnO}_{2}$ and $90 \% \mathrm{In}_{2} \mathrm{O}_{3} \mathrm{Wt} \%$. The 3" diameter $\mathrm{MZO}$ target contained $11 \% \mathrm{MgO}$ and $89 \% \mathrm{ZnO} \mathrm{Wt} \%$. The glass superstrates were rotated at $10 \mathrm{rpm}$ during deposition to enhance the uniformity of the films. The sputtering process was carried out at a constant power density of $3.5 \mathrm{~W} . \mathrm{cm}^{-2}$ and at a pressure of $133.3 \mathrm{~Pa}$ using $\mathrm{Ar}$ as the working gas. Sputtering of MZO films was carried out in a $1 \%$ $\mathrm{O}_{2}$ in an $\mathrm{Ar}$ atmosphere. The temperature of the superstrate was kept constant at $450{ }^{\circ} \mathrm{C}$ for the deposition of ITO and ranged from 20 to $400{ }^{\circ} \mathrm{C}$ for $\mathrm{MZO}$. The optical properties were investigated using a Cary Varian 5000 UV-VISNIR spectrophotometer. The composition of the films was measured using an X-ray photoelectron spectrometer (XPS) (Thermo Scientific K-alpha). Samples were processed into complete CdTe solar cells in the laboratories of University of Verona. ITO/MZO superstrates were coated with $\mathrm{CdS}$ and CdTe by thermal evaporation. The deposition process was carried out in a vacuum chamber at a pressure of $10^{-4}$ Pa with a Edwards XDS10 roughing pump and a Edwards ST-451 turbo-molecular pump. CdS was evaporated from a tungsten crucible at a deposition rate of $0.15 \mathrm{~nm} / \mathrm{sec}$. During deposition the substrate temperature was kept at $100{ }^{\circ} \mathrm{C}$ using halogen lamps. Before and after $\mathrm{CdS}$ deposition, the stack was annealed in vacuum at $450{ }^{\circ} \mathrm{C}$ for 30 minutes. $\mathrm{CdTe}$ was deposited from a special graphite Knudsen cell with an evaporation rate of $40 \AA / \mathrm{sec}$. The deposition rate was controlled using an Intellemetrics IL-150 quartz controller. The CdTe activation treatment was performed using a $\mathrm{CdCl}_{2}$ 
wet treatment. The solution was prepared by dissolving the $\mathrm{CdCl}_{2}$ powder in methanol to form a saturated solution. The $\mathrm{CdCl}_{2}$ powder was dried in a furnace at $0.1 \mathrm{~Pa}$ before processing in solution. Typically, $\approx 250 \mu \mathrm{l}$ is deposited in form of drops on the CdTe surface. The stack is then annealed in air at $380{ }^{\circ} \mathrm{C}$ for 30 minutes after a 15 minutes ramp from room temperature. Prior to back contact formation, the CdTe surface is treated with a solution of bromine $(50 \mathrm{ul})$ and methanol $(50 \mathrm{ml})$. This process removes residual $\mathrm{CdCl}_{2}$ and forms a Te-rich layer. Subsequently, a $2 \mathrm{~nm}$ thick layer of $\mathrm{Cu}$ and a $50 \mathrm{~nm}$ thick layer of $\mathrm{Au}$ are deposited by thermal evaporation at room temperature in a vacuum of $10^{-3}$ $\mathrm{Pa}$. The process is finished by annealing the structure for $20 \mathrm{~min}$ at $190{ }^{\circ} \mathrm{C}$ in air. Devices were characterized using current density-voltage (J-V) characteristics and cross-section images were obtained using transmission electron microscopy (TEM). Samples for TEM were prepared by focused ion beam milling using a dual beam FEI Nova 600 Nanolab. A standard in situ lift out method was used to prepare crosssectional samples. An electron beam assisted platinum(e-Pt) over-layer was deposited onto the sample surface above the area to be analysed followed by an ion assisted layer to define the surface and homogenize the final thinning of the samples down to $100 \mathrm{~nm}$. TEM analysis was carried out using a Tecnai F20 operating at $200 \mathrm{kV}$ to investigate the detailed microstructure of the cell cross sections. Images were obtained using the bright field (BF) detector.

\section{Characterization of Magnesium-Doped ZinC OXIDE FILMS}

Transmission plots of MZO films deposited at increasing temperatures are shown in Fig. 1(a). From the absorption edge in the UV region it is clear that the band gap of the films varies with the temperature of the substrate during deposition. The band gap of MZO films was estimated using the Tauc plot technique (Fig. 1(b)). The energy band gap of MZO films deposited at room temperature was estimated to be $E_{G}=3.65$ $\mathrm{eV}, 0.35 \mathrm{eV}$ higher than $\mathrm{ZnO}$. This confirms that doping $\mathrm{ZnO}$ with $\mathrm{Mg}$ widens the optical band gap of the semiconductor. It was also observed that raising the temperature assists further increase in $E_{G}$. $E_{G}$ increased from $3.65 \mathrm{eV}$ at room temperature to $3.95 \mathrm{eV}$ at $400{ }^{\circ} \mathrm{C}$, as previously reported [24]. XPS analysis showed that increasing the temperature during MZO film deposition leads to an increased concentration of $\mathrm{Mg}$ atoms as shown in Fig. 2. The Mg concentration increases up to $400{ }^{\circ} \mathrm{C}$ while the $\mathrm{Zn}$ concentration decreases up to 300 ${ }^{\circ} \mathrm{C}$. The oxygen concentration remains $\approx 41 \%$ at $20{ }^{\circ} \mathrm{C}, 100$ ${ }^{\circ} \mathrm{C}$ and $400{ }^{\circ} \mathrm{C}$ and significantly increases at 200 and $300{ }^{\circ} \mathrm{C}$. These results suggest that temperature enhances the inclusion of $\mathrm{Mg}$ ions in the MZO crystal structure. Evaporation of $\mathrm{Zn}$ or $\mathrm{Mg}$ during deposition can have an important role in this process. The vapourization temperature of $\mathrm{Zn}$ and $\mathrm{Mg}$ at a pressure of $1 \mathrm{mTorr}$ (used during deposition) is $\approx 290{ }^{\circ} \mathrm{C}$ and $\approx 380{ }^{\circ} \mathrm{C}$ respectively [25]. At $300^{\circ} \mathrm{C}$ and $400{ }^{\circ} \mathrm{C}$, the $\mathrm{Mg} / \mathrm{Zn}$ ratio increases significantly compared to films deposited at lower temperatures. $\mathrm{Zn}$ ions evaporate leaving free lattice
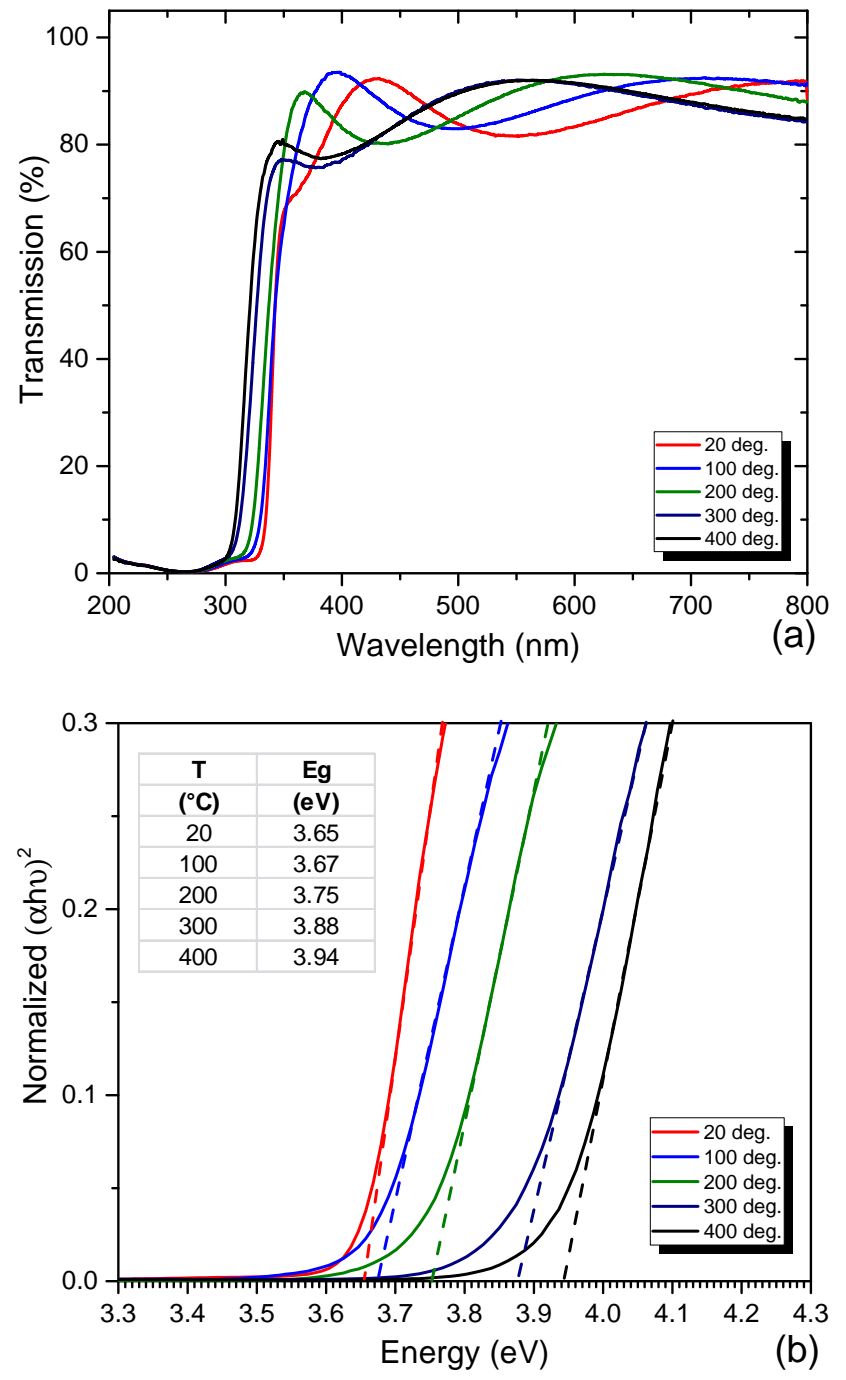

Fig. 1. The transmission spectra (a) and the Tauc plots (b) of MZO films deposited at temperature ranging between $20{ }^{\circ} \mathrm{C}$ and $400{ }^{\circ} \mathrm{C}$ showing respectively the shift of the absorption edge and the widening of the energy band gap in MZO films caused by the variation of the substrate temperature.

sites for $\mathrm{Mg}$ ions to occupy. $\mathrm{Up}$ to $200{ }^{\circ} \mathrm{C}$ the increasing $\mathrm{Mg}$ atomic concentration is not related to $\mathrm{Zn}$ evaporation but some other mechanism. Hwang et al have reported [24] that the increasing temperature causes a reduction of the $\mathrm{Mg}$ content in the films due to evaporation of $\mathrm{Mg}$ as measured using electron probe microanalysis. This is opposite to our findings. They also suggested that the increase in optical energy band gap occurs because raising temperature assists the replacement of $\mathrm{Zn}$ ions with $\mathrm{Mg}$ ions. Our work confirmed that temperature helps $\mathrm{Mg}$ ions replacing $\mathrm{Zn}$ ions. It was also confirmed that higher film deposition temperatures increase the MZO band gap. However the Mg concentration was found to grow by increasing temperature. The crystal structure of MZO has been investigated by XRD (Fig. 3). The (002) peak was observed, and the other peaks are associated with the underlying ITO film. The (002) peak was also observed for $\mathrm{ZnO}$ films [26] and is indexed from the crystallographic 


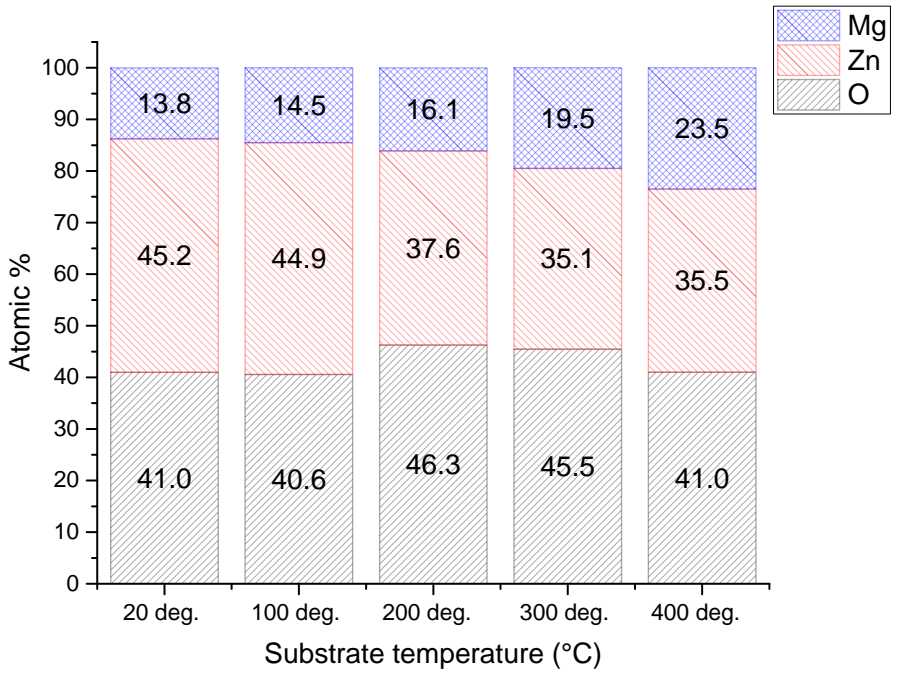

Fig. 2. The atomic percentage of $\mathrm{Mg}, \mathrm{ZnO}$ and $\mathrm{O}$ in $\mathrm{MZO}$ films estimated by XPS analysis showing the variation of the atomic ratios in MZO films caused by the variation of the substrate temperature.

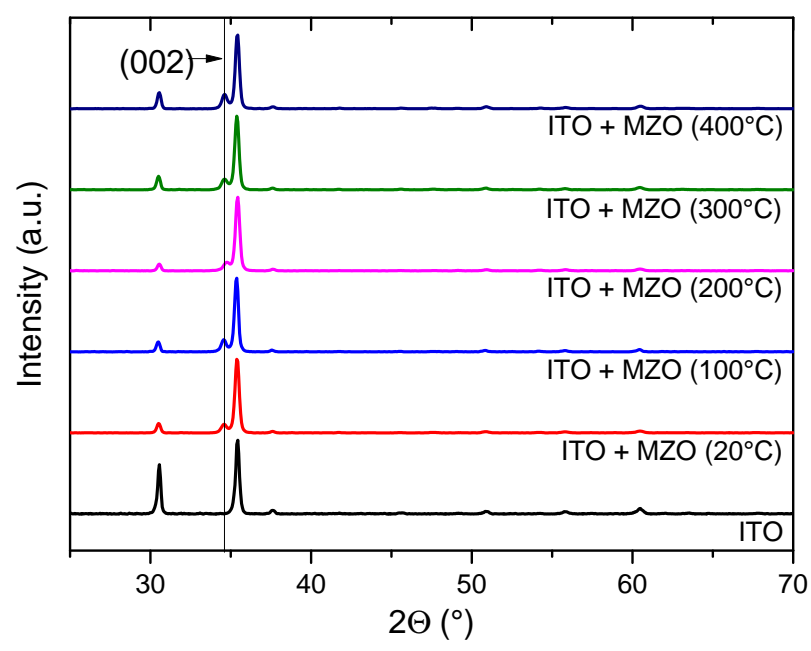

Fig. 3. The XRD patterns of MZO films deposited at different temperatures on ITO. The line highlights the position of the $(002)$ peak, typical of the hexagonal structure of $\mathrm{ZnO}$.

data of the $\mathrm{ZnO}$ hexagonal structure. Peaks (200) and (220) indexed from the crystallographic data of the cubic structure of $\mathrm{MgO}$, are not visible [5] (ICDD 00-003-0752). $\mathrm{ZnO}$ has a band gap of $3.3 \mathrm{eV}$ and a negative $\mathrm{CBO}$ with $\mathrm{CdS}$ of -0.3 $\mathrm{eV}$. Depositing MZO at room temperature provides an MZO film with a band gap of $3.65 \mathrm{eV}$ [7]. This corresponds to an almost flat conduction band alignment with CdS. Raising the deposition temperature of MZO increases the band gap to $3.95 \mathrm{eV}$ at $400{ }^{\circ} \mathrm{C}$. This corresponds to in a CBO with $\mathrm{CdS}$ of $+0.35 \mathrm{eV}$.

\section{A. Thermal Stability of MZO}

Multiple annealing steps are repeated during the fabrication process of thin film CdTe solar cells. The band gap of MZO films is sensitive to the temperature of the substrate during

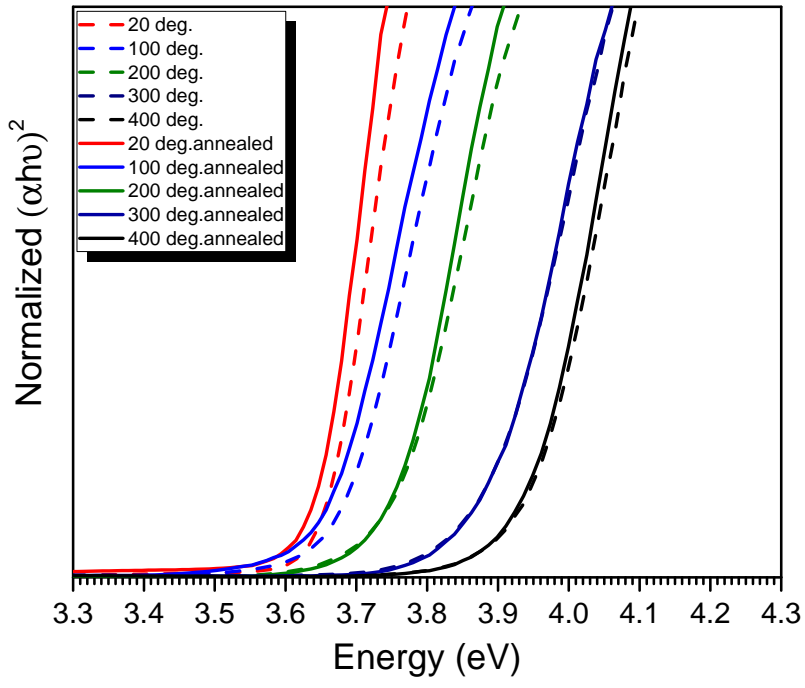

Fig. 4. Tauc plot of MZO films deposited at different temperatures (dashed lines) and of the same films annealed at $450{ }^{\circ} \mathrm{C}$ for 30 minutes(solid lines) showing the slight decrease of optical band gap that occurs after the MZO films are annealed at $450{ }^{\circ} \mathrm{C}$ for 30 minutes.

deposition. To test if the band gap of MZO can change during the fabrication process, a thermal annealing step was carried out at $450{ }^{\circ} \mathrm{C}$ for 30 minutes. This step simulates an equivalent annealing step used during the fabrication process. The band gaps of the films were extrapolated using the Tauc Plot technique (Fig. 4). The plot reveals that annealing the films at $450{ }^{\circ} \mathrm{C}$ slightly decreases the band gap of the films. The films deposited at lower temperatures result in a greater change in band gap. The change in all cases is small. The thin film deposited at room temperature changed the energy band gap from $3.65 \mathrm{eV}$ before annealing to $3.63 \mathrm{eV}$ post annealing. Similarly the film deposited at $100{ }^{\circ} \mathrm{C}$ decreased from 3.67 $\mathrm{eV}$ to $3.65 \mathrm{eV}$. These results suggest that the annealing steps carried out during the fabrication of $\mathrm{CdS} / \mathrm{CdTe}$ devices do not significantly change the energy band gap of the MZO layers.

\section{CDS/CdTe Solar Cells with MZO HRTs}

MZO films have been tested as HRT layers in CdS/CdTe solar cells with the structure ITO/MZO/CdS/CdTe/back contact. The performance of the devices was significantly affected by the deposition temperature of the MZO HRTs (Fig. 5). This suggests that the band gap of the MZO layer is playing a key role. The mean device efficiency increases from slightly below 5\% achieved with a room temperature deposited MZO to $\approx 10.6 \%$ at $400{ }^{\circ} \mathrm{C}$. The higher efficiency is a consequence of improved Voc and FF. Voc and FF of $0.82 \mathrm{~V}$ and $66 \%$ respectively were achieved with a deposition temperature of $400{ }^{\circ} \mathrm{C}$ for the $\mathrm{MZO}$ layer. Temperature has a detrimental effect on $\mathrm{Jsc}$ at $100^{\circ} \mathrm{C}$ while a further increase of temperature gradually improves the current density. The current density reaches a maximum at $300{ }^{\circ} \mathrm{C}$ and $400{ }^{\circ} \mathrm{C}\left(\approx 20 \mathrm{~mA} / \mathrm{cm}^{2}\right)$. Devices not containing the MZO HRTs were fabricated and the results have been compared. Efficiency, Voc and FF all benefit from the addition of MZO deposited at high temper- 
ature. The highest current densities achieved with MZO are similar to those achieved without the layer. This indicates that the high transparency of the films deposited at high temperature does not greatly affect the device current density.

\section{QUANTUM EFFICIENCY, TEM AND EDX ANALYSIS}

The EQE of the highest performing device, with an MZO layer deposited at $400{ }^{\circ} \mathrm{C}$ is shown in Fig. 6. The absorption edge in the near infra-red (NIR) region lies at $850 \mathrm{~nm}$, which corresponds to a typical band gap for the CdTe absorber of $1.45 \mathrm{eV}$ [27]. Whilst the device performance improves with MZO deposition temperature with improved Voc and $\mathrm{FF}$, the current density is limited by the high absorption in the blue region by the CdS. It is clear that to improve the device further, a reduction of thickness of the CdS layer is required. This would lead to higher photocurrent generation in the device. TEM images of the cross section of the sample show the layer by layer microstructure of the solar cell (Fig. 7). The thickness of the CdS layer has been estimated from the images to be in the range $250 \mathrm{~nm}-300 \mathrm{~nm}$. The CdS layer is sufficiently thick to absorb most of the radiation in the blue visible region. The CdTe layer is $\approx 7 \mu \mathrm{m}$ in thickness. The CdTe grains develop across the full width of the layer.

\section{Conclusions}

MZO films were deposited by magnetron sputtering at different substrate temperatures. It was confirmed that the addition of $\mathrm{Mg}$ to $\mathrm{ZnO}$ widens the band gap of the films. Increasing substrate temperature causes the band gap to widen further. These properties were utilized to produce MZO films with different $\mathrm{Eg}$ and to test them as HRT layers for CdTe thin film solar cells. The band gap of the MZO films ranged between $3.65 \mathrm{e} \mathrm{V}$ and $3.95 \mathrm{eV}$. A larger band gap was found to be beneficial for the Voc, FF and efficiency of devices. This suggests that the energy band alignment between HRT and CdS plays an important role in the performance of the solar cells. A thick CdS layer $(\approx 300 \mathrm{~nm})$ was used as a buffer layer leading to a low EQE response below $650 \mathrm{~nm}$. A thinner CdS should significantly improve the current density and the efficiency of these devices. This study provides evidence that MZO is a promising material as a HRT layer for thin film CdTe solar cells and highlights the importance of energy band alignment between adjacent semiconductors.

\section{ACKNOWLEDGMENT}

The authors are grateful to the Engineering and Physical Science Research Council (EPSRC) (EP/J017361/1) for financial assistance under the EPSRC Supergen SuperSolar Hub.

\section{REFERENCES}

[1] R. Ondo-Ndong, G. Ferblantier, M. Al Kalfioui, A. Boyer, and A. Foucaran, "Properties of RF magnetron sputtered zinc oxide thin films," Journal of Crystal Growth, vol. 255, pp. 130-135, jul 2003.

[2] K. Ellmer and A. Klein, "ZnO and Its Applications," pp. 1-33, 2008.

[3] X. Zhang, H. Ma, Q. Wang, J. Ma, F. Zong, H. Xiao, F. Ji, and S. Hou, "Structural and optical properties of MgxZn1-xO thin films deposited by magnetron sputtering," Physica B: Condensed Matter, vol. 364, pp. 157-161, jul 2005.
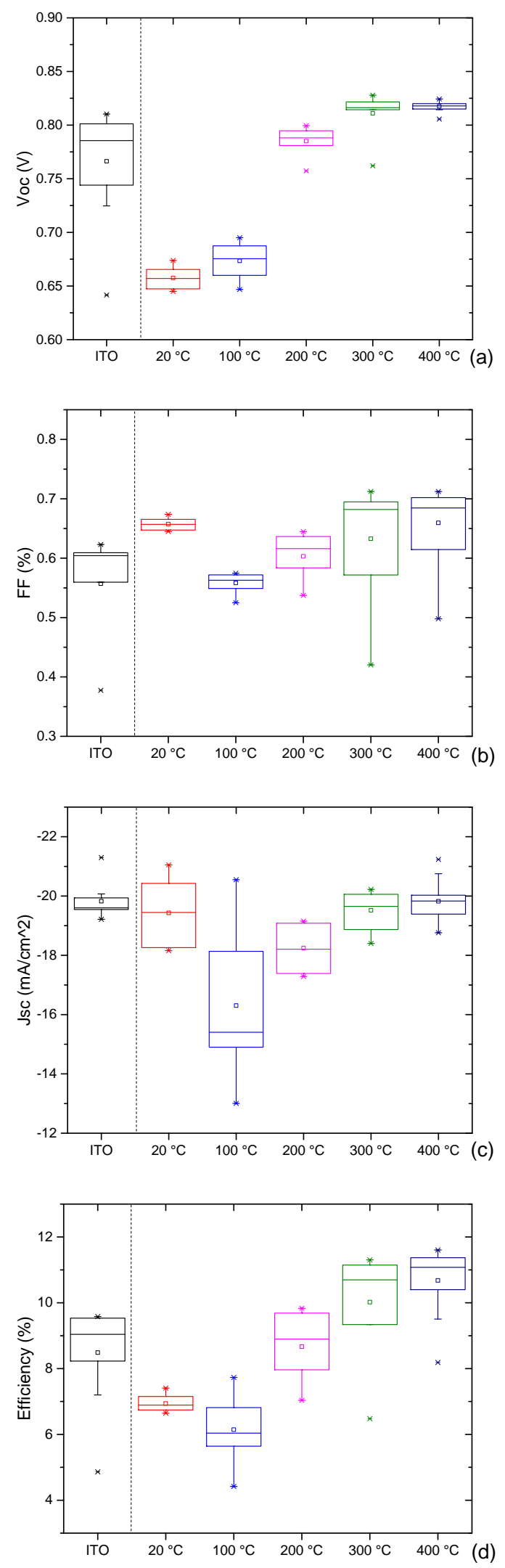

Fig. 5. Box Plots giving a statistical representation of Voc (a), FF (b), Jsc (c) and efficiency (d) of devices containing MZO deposited at increasing substrate temperature. 


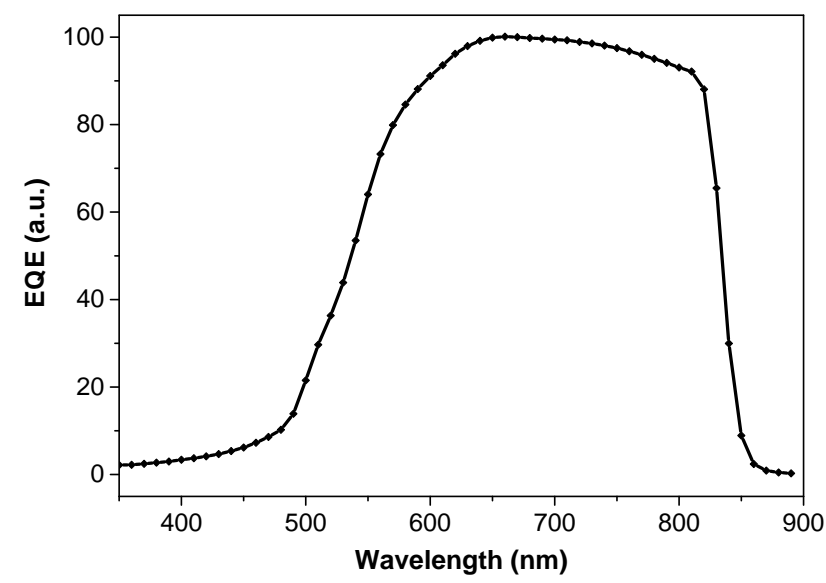

Fig. 6. The EQE spectra of a ITO/MZO/CdS/CdTe solar cell with MZO Eg $=3.94 \mathrm{eV}$ showing the low spectral response of the best performing device below $600 \mathrm{~nm}$ is due to the thick CdS layer absorption losses.

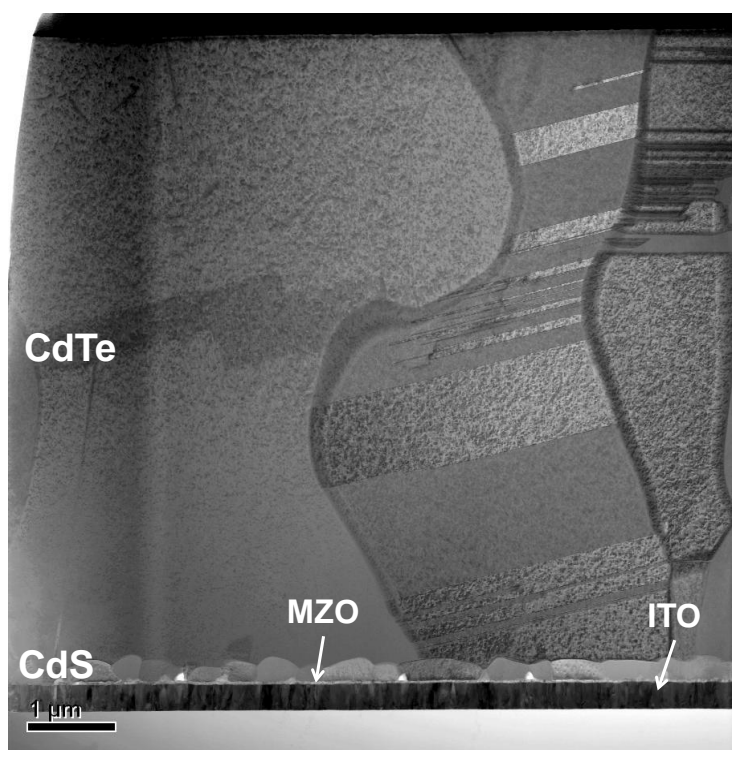

Fig. 7. A TEM cross-section of a full device. Starting from the top: the CdTe absorber, the CdS layer, the MZO HRT layer and the ITO layer.

[4] J.-H. Huang and C.-P. Liu, "The influence of magnesium and hydrogen introduction in sputtered zinc oxide thin films," Thin Solid Films, vol. 498, pp. 152-157, mar 2006.

[5] T. Minemoto, T. Negami, S. Nishiwaki, H. Takakura, and Y. Hamakawa, "Preparation of $\mathrm{Zn} 1-\mathrm{xMgxO}$ films by radio frequency magnetron sputtering," Thin Solid Films, vol. 372, pp. 173-176, sep 2000.

[6] A. Ohtomo, M. Kawasaki, I. Ohkubo, H. Koinuma, T. Yasuda, and Y. Segawa, "Structure and optical properties of $\mathrm{ZnO} / \mathrm{Mg} 0.2 \mathrm{Zn} 0.8 \mathrm{O}$ superlattices," Applied Physics Letters, vol. 75, pp. 980-982, aug 1999.

[7] G. V. Rao, F. Säuberlich, and A. Klein, "Influence of Mg content on the band alignment at $\mathrm{CdS} /(\mathrm{Zn}, \mathrm{Mg}) \mathrm{O}$ interfaces," Applied Physics Letters, vol. 87, p. 032101, jul 2005.

[8] L. Cao, J. Jiang, and L. Zhu, "Realization of band-gap engineering of $\mathrm{ZnO}$ thin films via Ca alloying," Materials Letters, vol. 100, pp. 201203, jun 2013.

[9] K. P. Misra, K. C. Dubey, R. K. Shukla, and A. Srivastava, "Reduction in carrier concentration by calcium doping in $\mathrm{ZnO}$ thin films," in 2009 International Conference on Emerging Trends in Electronic and Photonic Devices \& Systems, pp. 495-496, IEEE, dec 2009.
[10] J. Sites and J. Pan, "Strategies to increase CdTe solar-cell voltage," Thin Solid Films, vol. 515, pp. 6099-6102, may 2007.

[11] M. Gloeckler and J. Sites, "Efficiency limitations for wide-band-gap chalcopyrite solar cells," Thin Solid Films, vol. 480-481, pp. 241-245, jun 2005

[12] T. Song, A. Kanevce, and J. R. Sites, "Emitter/absorber interface of CdTe solar cells," Journal of Applied Physics, vol. 119, p. 233104, jun 2016.

[13] T. Minemoto, Y. Hashimoto, T. Satoh, T. Negami, H. Takakura, and Y. Hamakawa, "Cu(In,Ga)Se2 solar cells with controlled conduction band offset of window/Cu(In,Ga)Se2 layers," Journal of Applied Physics, vol. 89, pp. 8327-8330, jun 2001.

[14] T. Minemoto, Y. Hashimoto, W. Shamskolahi, T. Satoh, T. Negami, H. Takakura, and Y. Hamakawa, "Control of conduction band offset in wide-gap $\mathrm{Cu}(\mathrm{In}, \mathrm{Ga}) \mathrm{Se}$ solar cells," Solar Energy Materials and Solar Cells, vol. 75, pp. 121-126, jan 2003.

[15] G.-R. Uhm, S. Y. Jang, Y. H. Jeon, H. K. Yoon, and H. Seo, "Optimized electronic structure of a $\mathrm{Cu}(\mathrm{In}, \mathrm{Ga}) \mathrm{Se} 2$ solar cell with atomic layer deposited $\mathrm{Zn}(\mathrm{O}, \mathrm{S})$ buffer layer for high power conversion efficiency," RSC Advances, vol. 4, no. 53, p. 28111, 2014.

[16] N. Naghavi, D. Abou-Ras, N. Allsop, N. Barreau, S. Bücheler, A. Ennaoui, C.-H. Fischer, C. Guillen, D. Hariskos, J. Herrero, R. Klenk, K. Kushiya, D. Lincot, R. Menner, T. Nakada, C. Platzer-Björkman, S. Spiering, A. Tiwari, and T. Törndahl, "Buffer layers and transparent conducting oxides for chalcopyrite $\mathrm{Cu}(\mathrm{In}, \mathrm{Ga})(\mathrm{S}, \mathrm{Se}) 2$ based thin film photovoltaics: present status and current developments," Progress in Photovoltaics: Research and Applications, vol. 18, pp. 411-433, sep 2010.

[17] T. Törndahl, C. Platzer-Björkman, J. Kessler, and M. Edoff, "Atomic layer deposition of $\mathrm{Zn} 1-\mathrm{xMgxO}$ buffer layers for $\mathrm{Cu}(\mathrm{In}, \mathrm{Ga}) \mathrm{Se} 2$ solar cells," Progress in Photovoltaics: Research and Applications, vol. 15 , pp. 225-235, may 2007.

[18] J. Kephart, J. McCamy, Z. Ma, A. Ganjoo, F. Alamgir, and W. Sampath, "Band alignment of front contact layers for high-efficiency CdTe solar cells," Solar Energy Materials and Solar Cells, vol. 157, pp. 266-275, dec 2016.

[19] S. Sharbati and J. R. Sites, "Impact of the Band Offset for n-Zn(O,S)/p$\mathrm{Cu}(\mathrm{In}, \mathrm{Ga}) \mathrm{Se}$ Solar Cells," IEEE Journal of Photovoltaics, vol. 4, pp. 697-702, mar 2014.

[20] J. Perrenoud, S. Buecheler, L. Kranz, C. Fella, J. Skarp, and A. Tiwari, "Application of $\mathrm{ZnO}(1-\mathrm{x}) \mathrm{S}(\mathrm{x})$ as window layer in cadmium telluride solar cells," in 2010 35th IEEE Photovoltaic Specialists Conference, vol. 2, pp. 000995-001000, IEEE, jun 2010.

[21] D. M. Meysing, C. A. Wolden, M. M. Griffith, H. Mahabaduge, J. Pankow, M. O. Reese, J. M. Burst, W. L. Rance, and T. M. Barnes, "Properties of reactively sputtered oxygenated cadmium sulfide (CdS:O) and their impact on CdTe solar cell performance," Journal of Vacuum Science \& Technology A: Vacuum, Surfaces, and Films, vol. 33, p. 021203 , mar 2015.

[22] D. E. Swanson, S. R. Hafner, W. S. Sampath, and J. D. Williams, "Development of plasma enhanced closed space sublimation for the deposition of CdS:O in CdTe solar cells," in 2013 IEEE 39th Photovoltaic Specialists Conference (PVSC), pp. 0434-0437, IEEE, jun 2013.

[23] J. M. Kephart, R. Geisthardt, and W. Sampath, "Sputtered, oxygenated CdS window layers for higher current in CdS/CdTe thin film solar cells," in 2012 38th IEEE Photovoltaic Specialists Conference, pp. 000854-000858, IEEE, jun 2012.

[24] D.-K. Hwang, M.-C. Jeong, and J.-M. Myoung, "Effects of deposition temperature on the properties of $\mathrm{Zn} 1-\mathrm{xMgxO}$ thin films," Applied Surface Science, vol. 225, pp. 217-222, mar 2004.

[25] R. E. Honig, "Vapor pressure data for the solid and liquid elements," RCA Review, vol. 23, no. 4, pp. 567-586, 1962.

[26] F. Bittau, A. Abbas, K. Barth, J. Bowers, and J. Walls, "The effect of temperature on resistive $\mathrm{ZnO}$ layers and the performance of thin film CdTe solar cells," Thin Solid Films, nov 2016.

[27] B. E. McCandless and J. R. Sites, "Cadmium Telluride Solar Cells," in Handbook of Photovoltaic Science and Engineering, pp. 617-662, Chichester, UK: John Wiley \& Sons, Ltd, jan 2005. 